\title{
Increased activity of the antioxidants systems modulate the oxidative stress in saliva of toddlers with early childhood caries
}

\author{
Priscila Vieira da Silva ${ }^{\mathrm{a}, \mathrm{c}}$, Jéssica Antonini Troiano ${ }^{\mathrm{b}, \mathrm{d}}$, Ana Cláudia M.S. Nakamune ${ }^{\mathrm{b}, \mathrm{d}}$, \\ Juliano Pelim Pessan ${ }^{\mathrm{a}, \mathrm{c}}$, Cristina Antoniali ${ }^{\mathrm{a}, \mathrm{b}, \mathrm{d}, *}$ \\ ${ }^{a}$ Graduate Program in Dental Science, Araçatuba Dental School, UNESP - Univ Estadual Paulista, Rua José Bonifácio, 1193, Vila Mendonça, 16015-050 \\ Araçatuba, São Paulo, Brazil

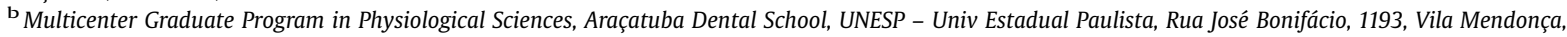 \\ 16015-050 Araçatuba, São Paulo, Brazil

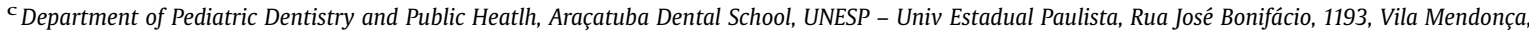 \\ 16015-050 Araçatuba, São Paulo, Brazil \\ ¿ Department of Basic Sciences, Araçatuba Dental School, UNESP - Univ Estadual Paulista, Rua José Bonifácio, 1193, Vila Mendonça, 16015-050 Araçatuba, São \\ Paulo, Brazil
}

\section{A R T I C L E I N F O}

\section{Article history:}

Received 3 December 2015

Received in revised form 31 May 2016

Accepted 1 June 2016

\section{Keywords:}

Dental caries

Children

Saliva

Oxidative stress

Superoxide dismutase

Uric acid

\begin{abstract}
A B S T R A C T
Objective: This study aimed to evaluate the oxidative stress levels and the enzymatic and non-enzymatic antioxidant systems in saliva of toddlers with severe early childhood caries (S-ECC).

Design: Unstimulated saliva samples were collected at the morning from 0 to 3 year-old S-ECC $(n=30)$ or caries-free (CF) children ( $\mathrm{n}=30$ /group) for evaluation of oxidative stress (OS) and total antioxidant capacity (TAC), which were measured by the ferric reducing antioxidant power (FRAP) assay, as well as to assess the activity of enzymatic (superoxide dismutase, SOD) and non-enzymatic (uric acid, UA) antioxidant systems, respectively. Data were analyzed by Student's $t$-test $(\mathrm{p}<0.05)$.

Results: Significantly higher protein levels were observed in saliva of S-ECC children $(0.083 \mathrm{mg} / \mathrm{mL})$ than in the CF group $(0.070 \mathrm{mg} / \mathrm{mL})$. Oxidative damage was significantly lower in saliva of S-ECC children $(0.0019 \mu \mathrm{mol} / \mathrm{L} / \mathrm{mg}$ protein $)$ than in $\mathrm{CF}$ children $(0.0039 \mu \mathrm{mol} / \mathrm{L} / \mathrm{mg}$ protein $)$, while salivary TAC $(61.5 \mu \mathrm{mol} / \mathrm{L})$, SOD activity $(36.6 \mathrm{UE} / \mathrm{mL})$ and uric acid $(7.05 \mathrm{mg} / \mathrm{mL})$ were significantly higher in saliva of S-ECC when compared to the CF group $(49.1 \mu \mathrm{mol} / \mathrm{L}, 26.8 \mathrm{UE} / \mathrm{mL}$ and $5.02 \mathrm{mg} / \mathrm{mL}$, respectively for TAC, SOD and UA).

Conclusion: Oxidative stress levels were significantly lower in saliva of S-ECC children, what might be associated with the increased activity of salivary enzymatic (SOD) and non-enzymatic (uric acid) antioxidant systems.
\end{abstract}

(c) 2016 Elsevier Ltd. All rights reserved.

\section{Introduction}

Severe early childhood caries (S-ECC) is one of the most common oral diseases in children. S-ECC is defined by the European Academy of Pediatric Dentistry as the presence of one or more primary decayed tooth (cavitated lesions or not), missing (due to caries) or restored tooth surfaces before 71 months of age (Vadiakas, 2008), while the American Academy of Pediatric Dentistry defines as severe S-ECC as any sign of smooth-surface caries in children younger than three years of age (American

\footnotetext{
* Corresponding author at: Araçatuba Dental School, UNESP - Univ Estadual Paulista, Department of Biological Sciences, José Bonifácio 1193, 16015-050 Araçatuba, São Paulo, Brazil.

E-mail address: crisant@foa.unesp.br (C. Antoniali).
}

Academy of Pediatric Dentistry, 2014). High prevalence rates of S-ECC have been reported in developed and in developing countries, ranging from 46 to $96 \%$ in 3-7-year-old children, reaching levels up to $17 \%$ in $0-3$-year-old children from lowincome communities or where the access to dental services is difficult by political, economic and social factors(Grund, Goddon, Schüler, Lehmann, \& Heinrich-Weltzien, 2015; Warren et al., 2016).

Biomarkers of oxidative damage are found in saliva as 8-hydroxy-desoxguanosine (8-Hodgkins) and malondialdehyde (MDA). Enzymatic antioxidants - glutathione peroxidase (GPX) and superoxide dismutase (SOD) - can be measured in saliva and other biological fluids, similarly as for the non-enzymatic antioxidant systems, which include uric acid (UA) and glutathione (GSH) and comprise the non-enzymatic total antioxidant capacity (TAC) (Battino, Ferreiro, Gallardo, Newman, \& Bullon, 2002). Oxidative 
stress is attributed to an imbalance between free radical production, as reactive oxygen species (ROS), and the activity of enzymatic and non-enzymatic antioxidant systems, which are a powerful defense of body against damages caused by free radicals (Kirschvink, De Moffarts, \& Lekeux, 2008; Tunez et al., 2007).

Increased oxidative damage biomarkers have been observed in saliva of individuals presenting periodontal disease or dental caries (Battino et al., 2002; Tóthová, Celecová, \& Celec, 2003). Conversely, TAC of stimulated saliva has been shown to be significantly decreased in patients with periodontal disease (Diab-Ladki, Pellat, \& Chahine, 2003), and in saliva of patients with peri-implant desease (Liskmann et al., 2007). However, unlike what would be expected, the levels of TAC were significantly higher in saliva of children, adolescents and adults presenting carious lesions in comparison with caries-free subjects (Ahmadi-Motamayel, Goodarzi, Hendi, Kasraei, \& Moghimbeigi, 2013; Hegde, Rai, \& Padmanabhan, 2009; Kumar, Pandey, \& Agrawal, 2011; Mahjoup, Ghasempour, Gharage, Bijani, \& Masrourroudsari, 2014; Hegde, Hegde, Ashok, \& Shetty, 2013). These results indicate that the relationship between oxidative stress and the antioxidant systems in saliva of individuals with caries activity is not fully understood. In fact, the association between TAC and oxidative damage has not yet been evaluated in S-ECC children. In addition, no data is available on the role of non-enzymatic antioxidant system, such as uric acid, in saliva of patients with caries. Finally, and most importantly, while studies have reported isolated data on the effects of oxidative damage and TAC in S-ECC children, these aspects have not been collectively evaluated in the same group of children, so that the relationship between these variables could not be determined.

Therefore, this study aimed to evaluate the oxidative stress levels and the enzymatic (SOD) and non-enzymatic (uric acid) antioxidant systems in saliva of children in early childhood (0-3 years old) presenting S-ECC. The study's hypothesis was that oxidative stress levels and enzymatic and non-enzymatic antioxidant systems would be increased in saliva of children with caries lesions.

\section{Materials and methods}

\subsection{Patient selection}

The research protocol was approved by the Human Ethics Committee of Araçatuba Dental School, UNESP- Univ. Estadual Paulista (Permission Number CAAE 36416414.5.0000.542). Children at the age range of $0-3$ years were selected from public kindergartens in the city of Araçatuba, State of São Paulo, Brazil. An initial meeting was conducted with directors of kindergartens and parents of the children to explain in details the study protocol and to answer to possible questions raised by the attendants. Following, free and informed consent forms were distributed to all parents/caregivers, and those who were unsigned entered as exclusion criteria, along with children presenting systemic diseases. From the signed informed consent forms returned to the researchers, clinical examinations were performed in 100 children, for the determination of dmfs index based on World Health Organization recommendation (WHO, 1997), performed by a calibrated dentist (PVS). Subsequently, sixty children were randomly enrolled in the study (blocking stratification), comprising 30 subjects with severe early childhood caries (S-ECC group) and 30 caries-free (CF group) (Vadiakas, 2008).

\subsection{Saliva collection}

To minimize possible variation due to circadian rhythm, unstimulated whole saliva was collected between 7:00 am to
8:30 am, $2 \mathrm{~h}$ after fasting and oral hygiene with water and toothbrush without fluoride products. All salivary samples were collected by the same investigator within kindergartens during 5 min, using a Salivette ${ }^{\circledR}$ (Sarstedt, Germany). Samples were kept on ice during collection and then were centrifuged at $5500 \mathrm{~g}$ for $10 \mathrm{~min}$ as previously described (Cunha-Correia, Neto, Pereira, Aguiar, \& Nakamune, 2014). The supernatants were fractionated and kept at $-80^{\circ} \mathrm{C}$ until analysis.

\subsection{Determination of total protein concentration}

Protein was measured by the method of Lowry, Rosebrough, Farr, and Randall (1951) with bovine serum albumin used as standard. The absorbance was determined at $660 \mathrm{~nm}$. The results were expressed in $\mathrm{mg} / \mathrm{mL}$.

\subsection{Measurement of malondialdehyde (MDA)}

MDA is one of the products of lipid peroxidation evaluated by the method thiobarbituric acid-reactive substances (TBARS), which has been considered a biomarker of oxidative stress. MDA was determined as described by Buege and Aust (Buege and Aust, $1978)$. Trichloroacetic acid (10\% w/v) was added to the saliva samples $(125 \mu \mathrm{L})$ to precipitate proteins and to acidify the reaction solution. This mixture was then centrifuged (1000g, $3 \mathrm{~min}$ ) and thiobarbituric acid (TBARS, $0.67 \% \mathrm{w} / \mathrm{v}$ ) was added to the reaction medium. The sample was placed in a water bath $\left(100^{\circ} \mathrm{C}, 15 \mathrm{~min}\right)$. The absorbance was read at $535 \mathrm{~nm}$, the molar absorption coefficient used was $1.56 \times 105 \mathrm{M}^{-1} \mathrm{~cm}^{-1}$. The results are expressed $\mu \mathrm{mol} / \mathrm{L} / \mathrm{mg}$ protein.

\subsection{Salivary total antioxidant capacity}

Salivary total antioxidant capacity was assessed by ferric reducing antioxidant power (FRAP) assay (Benzie \& Strain, 1996). This method is based on reducing the ferric complex tripiridil triazine ( $\mathrm{Fe}^{3+} \mathrm{TPTZ}$ ) to form $\mathrm{Fe}^{2+}$ in acidic medium. An aliquot of saliva $(15 \mu \mathrm{L})$ was used and the absorbance was determined at $595 \mathrm{~nm}$, using a standard curve of ferrous sulfate. The results are expressed in $\mu \mathrm{mol} / \mathrm{L} \mathrm{FeSO}_{4}$.

\subsection{Superoxide dismutase (SOD) activity}

SOD activity was determined in saliva by the method of Maklund (1985) based on the inhibition of the pyrogallol autoxidation, using an aliquot of saliva $(20 \mu \mathrm{L})$ previously diluted in tris $(1: 10 \mathrm{v} / \mathrm{v})$. Absorbance was detected at $420 \mathrm{~nm}$. The amount of enzyme required to inhibit $50 \%$ of the autoxidation of pyrogallol was considered as a unit of enzyme activity. Results are expressed as $\mathrm{UE} / \mathrm{mL}$.

\subsection{Uric acid}

Uric acid was determined in saliva using a commercial kit (Labtest Diadgnóstica SA, MG, Brazil) based on enzymatic Trinder method, following the manufacturer's instructions. The results are expressed in $\mathrm{mg} / \mathrm{ml}$.

\subsection{Statistical analysis}

Data are expressed as mean \pm SD (Standard Deviation). Statistical analysis of the results was performed using independent Student $t$-test (Graph Pad Prism, 5.0 version). Values of $\mathrm{p}<0.05$ were considered as statistically significant. 


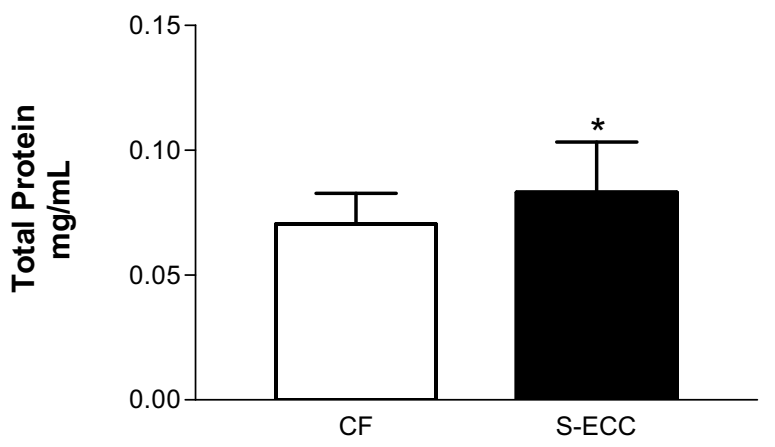

Fig. 1. Total protein $(\mathrm{mg} / \mathrm{mL})$ in saliva of caries-free $(\mathrm{CF})$ and severe early childhood caries (S-ECC) groups. Bars represent mean $\pm \mathrm{SD}$. ${ }^{*} \mathrm{p}<0.05$ (Student's $t$-test).

\section{Results}

Sixty children aged 0-3 years participated in this study, twentynine boys and thirty one girls. Within the S-ECC group $(n=30), 47 \%$ and 53\% were boys and girls, respectively, while the corresponding percentages for the CF group $(n=30)$ were $53 \%$ and $47 \%$, respectively. Mean number of cavitated surfaces (dmfs) in the S-ECC group was $3.7 \pm 3.44$.

\subsection{Salivary total protein}

Salivary total protein was significantly higher $(\mathrm{p}<0.01)$ in the S-ECC group $(0.083 \pm 0.020 \mathrm{mg} / \mathrm{mL})$ when compared to CF group $(0.070 \pm 0.012 \mathrm{mg} / \mathrm{mL})$ (Fig. 1).

\subsection{Salivary MDA levels}

Salivary MDA levels were significantly lower $(\mathrm{p}<0.0001)$ in the S-ECC group $(0.0019 \pm 0.0008 \mu \mathrm{mol} / \mathrm{L} / \mathrm{mg}$ protein $)$ than in $\mathrm{CF}$ group $(0.039 \pm 0.0021 \mu \mathrm{mol} / \mathrm{L} / \mathrm{mg}$ protein) (Fig. 2$)$.

\subsection{TAC in saliva evaluation}

TAC in saliva was significantly higher $(\mathrm{p}<0.05)$ in S-ECC group $(61.5 \pm 20.18 \mu \mathrm{mol} / \mathrm{L})$ compared to the CF group $(49.1 \pm 23.24 \mu \mathrm{mol} / \mathrm{L})$ (Fig. 3).

\subsection{Enzymatic salivary antioxidant activity}

SOD activity $(36.6 \pm 22.79 \mathrm{UE} / \mathrm{mL})$ was significantly higher in SECC $(\mathrm{p}<0.05)$ when compared to the CF group $(26.8 \pm 9.09 \mathrm{UE} / \mathrm{mL})$ (Fig. 4).

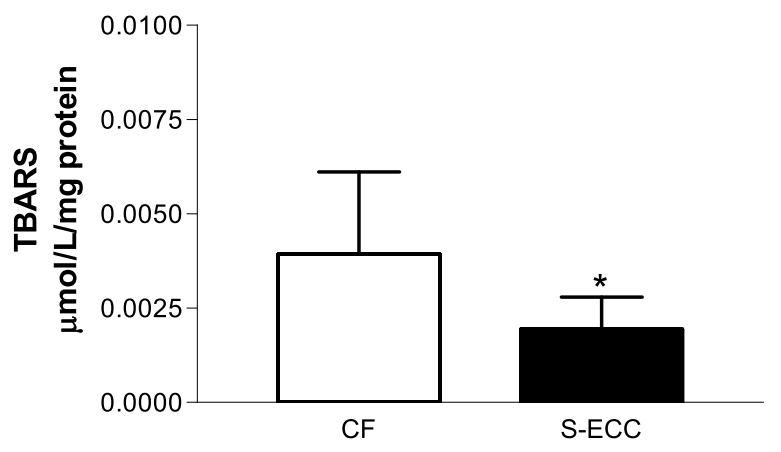

Fig. 2. Concentration of 2-thiobarbituric acid-reactive substances (TBARS, in nmol/ $\mathrm{mg}$ protein) in saliva caries-free (CF) and severe early childhood caries (S-ECC) groups. Bars represent the mean $\pm \mathrm{SD} .{ }^{*} \mathrm{p}<0.05$ (Student's $t$-test).

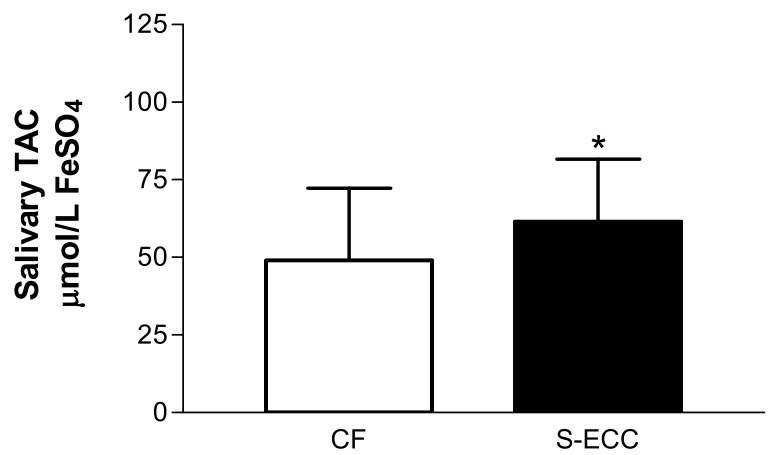

Fig. 3. Total Antioxidant Capacity (TAC, $\mu \mathrm{mol} / \mathrm{L} \mathrm{FeSO}_{4}$ ) in saliva of caries-free (CF) and severe early childhood caries (S-ECC) groups. Bars represent the mean $\pm \mathrm{SD}$. ${ }^{*} \mathrm{p}<0.05$ (Student's $t$-test).

\subsection{Non-enzymatic salivary antioxidant activity}

Salivary uric acid values were significantly increased $(\mathrm{p}<0.0001)$ in S-ECC group $(7.05 \pm 1.40 \mathrm{mg} / \mathrm{mL})$ than in the $\mathrm{CF}$ group $(5.02 \pm 1.61 \mathrm{mg} / \mathrm{mL})$ (Fig. 5).

\section{Discussion}

In this study, oxidative damage levels were significantly lower in saliva of S-ECC children, while increased activity of salivary enzymatic and non-enzymatic antioxidant systems were increased in this group of children. Therefore, the study's hypothesis was partially accepted. Since no study had assessed oxidative stress and

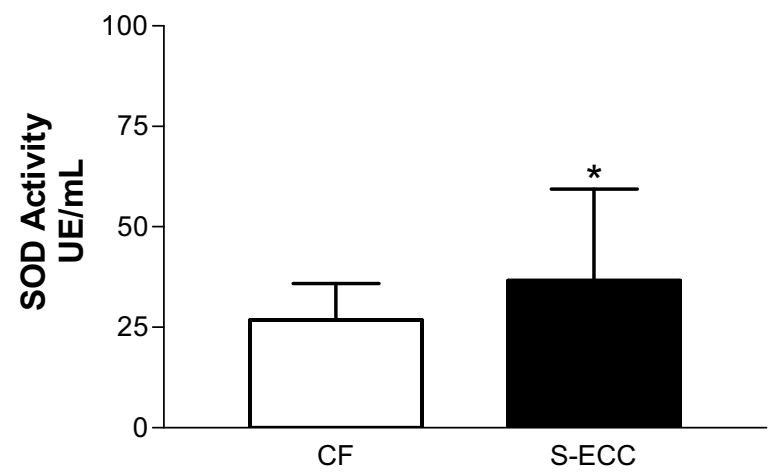

Fig. 4. Superoxide dismutase (SOD) activity (UE/mL) in saliva caries-free (CF) and severe early childhood caries (S-ECC) groups. Bars represent the mean $\pm S D$. ${ }^{*} \mathrm{p}<0.05$ (Student's $t$-test)

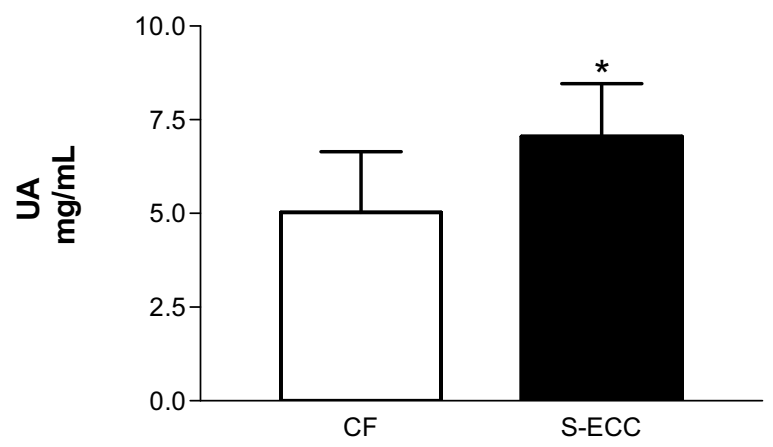

Fig. 5. Uric acid (UA, in $\mathrm{mg} / \mathrm{mL}$ ) in saliva of caries-free (CF) and severe early childhood caries (S-ECC) groups. Bars represent the mean \pm SD. * $\mathrm{p}<0.05$ (Student's t-test). 
antioxidant system salivary profile in S-ECC children, the present findings bring novel information to the field.

The concentration of salivary total protein was higher in S-ECC children than in CF group. These results are in line with previous data demonstrating increased concentration of total protein in saliva of children and adults diagnosed with pneumonia (Kremer, Kuzminsky, Bentur, \& Nagler, 2014), cystic fibrosis (Livnat, Bentur, Kuzmisnky, \& Nagler, 2010), and in children with severe caries (Hegde et al., 2009). It is possible that the higher protein concentration in saliva of S-ECC children would be a protective and/or an adaptive response of the body against dental caries, given that salivary proteins have a protective role of oral tissues by forming a film of protein against enamel wear, preventing the adherence and growth of microorganisms, promoting the remineralization of enamel by attracting calcium ions, and reducing enamel demineralization in association with salivary calcium and phosphate ions (Amerongen, Bolscher, \& Veerman, 2004).

Reduced levels of TBARS were observed in saliva of S-ECC children when compared to $\mathrm{CF}$ children, suggesting reduced oxidative damage in the saliva of children presenting caries lesions. These results are in agreement with a previous work conducted with caries-active adults (17-50 years old) (Öztürk et al., 2008; Sarode, Shelar, Sarode, \& Bagul, 2012), and patients (16-46 years old) with periodontal disease and gingivitis (Celec et al., 2005; Almerich-Silla et al., 2015). However, variable levels of salivary OS of adults have been reported when associated to oral infectious diseases. No difference in salivary MDA levels (Öztürk et al., 2008) was observed, or higher lipid peroxidation was detected in saliva of adults with active caries than in caries-free group (Rai, Jain, \& Anand, 2006). Moreover, the increased OS, which was observed in saliva of patients with oral lichen planus (25-75 years old), squamous cell carcinoma (34-82 years old) or periodontal disease, was associated with a reduced salivary TAC (Agha-Hosseini, Mirzaii-Dizgah, Farmanbar, \& Abdollahi, 2012; Baltacioglu et al., 2014; Sculley \& Langley-Evans, 2003).

Salivary TAC in S-ECC group was significantly higher than in CF group in the present study, in line with previous reports in children (3-5 years old) from North Iran (Mahjoup et al., 2014). In addition, a strong correlation between the number of decayed teeth and increased salivary TAC in children (3-5 years old) of India has been reported (WHO, 1997). An indirect correlation between reduced salivary $\mathrm{pH}$ and increased salivary TAC was observed in children (3-5 years old) (Muchandi et al., 2015) from India. Together, these results corroborated the suggestion that high salivary TAC is a biomarker of caries in children (Tulunoglu, Demirtas, \& Tulunoglu, 2006), adolescents (Ahmadi-Motamayel et al., 2013) and adults (Hegde et al., 2009). As recently suggested (Tóthova, Kamodyová, Cervenka, \& Celec, 2015), salivary markers of oxidative stress have the potential to be used for screening and monitoring oral diseases, including dental as caries. The evaluation of these markers in saliva could be an adjuvant toll for identification of patients with poor adherence to dental visits. Furthermore, the study of such biomarkers could bring useful information for the development of novel therapies for the prevention and/or treatment of dental caries. Such makers, however, should be validated in future studies conducted with a larger number of subjects and taking into account varying levels of caries.

Based on the considerations above, we assessed whether TAC would involve the action of antioxidants systems in saliva of children presenting ECC, by evaluating the concentration of uric acid, which has been assessed in saliva of patients as a nonenzymatic antioxidant biomarker. It has been suggested that the increase in uric acid levels in saliva may influence TAC levels (Kumar et al., 2011) since uric acid is responsible for around than $70 \%$ of salivary antioxidant capacity (Nagler, Klein, Zarzhevsk, Drigues, \& Reznick, 2002). While uric acid was assessed in saliva of patients with cystic fibrosis (Livnat et al., 2010), chronic periodontitis (Miricescu et al., 2014) and in patients with cleft lip (Aizenbud, Peri-Front, \& Nagler, 2008), to the best of our knowledge uric acid had not been previously assessed in saliva of S-ECC children. In the present study, significantly higher uric acid antioxidant response was observed in saliva of S-ECC group, which contributed to the increase in salivary TAC levels of these children. A significant increase in SOD activity in saliva of the S-ECC group was observed in the present study, which might also have contributed to the lower oxidative damage in these children. The evaluation of saliva of caries active adults (25-50 years) also demonstrated increased levels of SOD and its cofactors, copper and zinc (Hegde, Hegde, Ashok, \& Shetty, 2014). Previous studies observed higher SOD activity in patients with cleft lip and with cystic fibrosis (Livnat et al., 2010). SOD activity, which has been considered as the first line of enzymatic antioxidant defense in the organism, catalyzes the dismutation of superoxide ion (an oxygen free radical) into oxygen and hydrogen peroxide (Varvara, Traini, Esposito, Caputi, \& Perinetti, 2005).

Since saliva can be used for long-term monitoring oral diseases and considering the lack of conclusive studies about oxidative stress in saliva of caries active subjects (Tóthova et al., 2015), our results suggest a salivary profile of ECC children: increased salivary proteins, reduced oxidative damage, increased TAC or FRAP and uric acid, and increased SOD activity. The reasons for the increased non-enzymatic or enzymatic antioxidant status in saliva of cariesactive subjects, however, remain unclear. Given that their function is to protect oral tissues against the deleterious effects of endogenous or exogenous oxygen or nitrogen reactive species, our results suggest that the increased UA and SOD activity might be a compensatory mechanism to reduce oxidative damage.

Based on the results of the present study, we can conclude that oxidative damage is reduced in saliva of S-ECC children as a consequence of the increased non-enzymatic and enzymatic antioxidant systems.

\section{Conflicts of interest}

The authors declare that there are no conflicts of interest.

\section{Funding}

We thank CAPES-PROAP and Programa de Pós-Graduação em Ciência Odontológica for financial support. Priscila Vieira da Silva was the recipient of fellowship from CAPES.

\section{Ethical approval}

The Research Protocol was approved by the Human Ethics Committee of Araçatuba Dental School, UNESP - Univ Estadual Paulista (Permission Number CAAE 36416414.5.0000.542).

\section{Acknowledgments}

We thank CAPES-PROAP and Programa de Pós-Graduação em Ciência Odontológica for financial support. Priscila Vieira da Silva was the recipient of fellowship from CAPES.

\section{References}

Agha-Hosseini, F., Mirzaii-Dizgah, I., Farmanbar, N., \& Abdollahi, M. (2012). Oxidative stress status and DNA damage in saliva of human subjects with oral lichen planus and oral squamous cell carcinoma. Journal of Oral Pathology and Medicine, 41, 736-740.

Ahmadi-Motamayel, F., Goodarzi, M. T., Hendi, S. S., Kasraei, S., \& Moghimbeigi, A. (2013). Total antioxidant capacity of saliva and dental caries. Medicina Oral Patol Oral Y Cirurgia Bucal, 18, 553-556. 
Aizenbud, D., Peri-Front, Y., \& Nagler, R. M. (2008). Salivary analysis and antioxidants in cleft lip and palate children. Achives of Oral Biology, 53, 517-522.

Almerich-Silla, J. M., Montiel-Company, J. M., Pastor, S., Serrano, F., Puig-Silla, M., \& Dasí, F. (2015). Oxidative stress parameters in saliva and its association with periodontal disease and types of bacteria. Disease Markers, 2015, 1-7.

American Academy of Pediatric Dentistry (2014). Policy on early childhood caries (ECC): classifications, consequences, and preventive strategies. Pediatric Dentistry, 37, 15-16.

Amerongen, A. V. N., Bolscher, J. G. M., \& Veerman, E. C. I. (2004). Salivary proteins: protective and diagnostic value in cariology? Caries Research, 38, 247-253.

Baltacioglu, E., Yuva, P., Aydin, G., Alver, A., Kahraman, C., Karabulut, E., et al. (2014). Lipid peroxidation levels and total oxidant/antioxidant status in serum and saliva from patients with chronic and aggressive periodontitis. Oxidative stress index: a new biomarker for periodontal disease? Journal Periodontology, 85, 1432-1441.

Battino, M., Ferreiro, M. S., Gallardo, I., Newman, H. N., \& Bullon, P. (2002). The antioxidant capacity of saliva. Journal of Clinical Periodontology, 29, 189-194.

Benzie, I. F., \& Strain, J. J. (1996). The ferric reducing ability of plasma as a measure of 'antioxidant power': the FRAP assay. Analytical Biochemistry, 239, 70-76.

Buege, J. A., \& Aust, S. D. (1978). Microsomal lipid peroxidation. Methods in Enzymology, 52, 302-310.

Celec, P., Hodosya, J., Celecovac, V., Vodrazkad, J., Cervenkaa, T., Halcaka, L., et al. (2005). Salivary thiobarbituric acid reacting substances and malondialdehydetheir relationship to reported smoking and to parodontal status described by the papillary bleeding index. Disease Markers, 21, 133-137.

Cunha-Correia, A. S., Neto, A. H., Pereira, A. F., Aguiar, S. M. H. C. A., \& Nakamune, A. C. M. S. (2014). Enteral nutrition feeding alters antioxidante activity in unstimulated whole saliva composition of patients with neurological disorders. Research in Developmental Disabilities, 35, 1209-1215.

Diab-Ladki, R., Pellat, B., \& Chahine, R. (2003). Deacrease in the antioxidant activity of saliva in patients with periodontal disease. Clinical Oral Investigations, 7, 103107.

Grund, K., Goddon, I., Schüler, I. M., Lehmann, T., \& Heinrich-Weltzien, R. H. (2015). Clinical consequences of untreated dental caries in German 5- and 8-year-olds. BioMedCentral Oral Health, 15, 140.

Hegde, A. M., Rai, K., \& Padmanabhan, V. (2009). Total antioxidant capacity of saliva and its relation with early childhood caries and rampant caries. Journal of Clinical Pediatric Dentistry, 33, 231-234.

Hegde, M. N., Hegde, N. D., Ashok, A., \& Shetty, S. (2013). Evaluation of total antioxidant capacity of saliva and serum in caries-free and caries-active adults: an in-vivo study. Indian Journal of Dental Research, 24, 164-167.

Hegde, M. N., Hegde, N. D., Ashok, A., \& Shetty, S. (2014). Biochemical indicators of dental caries in saliva: an in vivo study. Caries Research, 48, 170-173.

Kirschvink, N., De Moffarts, B., \& Lekeux, P. (2008). The oxidant/antioxidant equilibrium in horses. Veterinary Journal, 177, 178-191.

Kremer, A. K., Kuzminsky, E., Bentur, L., \& Nagler, R. M. (2014). Salivary and serum analysis in children diagnosed with pneumonia. Pediatric Pulmonology, 49, 569573.

Kumar, D., Pandey, R. K., \& Agrawal, D. (2011). Anestimation and evaluation of total antioxidant capacity of saliva in children with severe early childhood caries. International Journal Pediatric Dentistry, 21, 456-464.

Liskmann, S., Vihalemm, T., Salum, O., Zilmer, K., Fischer, K., \& Zilmer, M. (2007). Characterization of the antioxidant profile of human saliva in peri-implant health and disease. Clinical Oral Implants Research, 18, 27-33.

Livnat, G., Bentur, L., Kuzmisnky, E., \& Nagler, R. M. (2010). Salivary profile and oxidative stress in children and adolescents with cystic fibrosis. Journal of Oral Pathololgy E Medicine, 39, 16-21.
Lowry, O. H., Rosebrough, A. L., Farr, A. L., \& Randall, R. (1951). Protein measurement whit the folin phenol reagent. The Journal Biological Chemistry, 193, 265-275.

Mahjoup, S., Ghasempour, M., Gharage, A., Bijani, A., \& Masrourroudsari, J. (2014). Comparison of Total antioxidant Capacity in saliva of children with severe early childhood caries and caries-free children. Caries Research, 48, 271-275.

Maklund, S. (1985). Pyrogallol auto oxidation. In R. A. Greenwald (Ed.), Handbook of methods for oxygen radical research (pp. 243-247).Boca Raton: CRC Press.

Miricescu, D., Totan, A., Calenic, B., Mocanu, B., Didilescu, A., Mohora, M., et al. (2014). Salivary biomarkers: relationship between stress and alveolar bone loss in chronic periodontitis. Acta Odontologica Scandinavica, 72, 42-47.

Muchandi, S., Walimbe, H., Bijle, M. N., Nankar M., Chaturvedi, S., \& Karekar, P. (2015). Comparative evaluation and correlation of salivary total antioxidant capacity and salivary $\mathrm{pH}$ in caries-free and severe early childhood caries children. The Journal of Contemporany Dental Practice, 16, 234-237.

Nagler, R. M., Klein, I., Zarzhevsk, N., Drigues, N., \& Reznick, A. Z. (2002) Chacacterization of the differentiated antioxidante profile of human saliva. Free Radical Biology and Medicine, 32, 268-277.

Öztürk, L. K., Furuncuoglu, H., Atala, M. H., Uluköylü, O., Akyüz, S., \& Yarat, A. (2008) Association between dental-oral health in young adults and salivary glutathione: lipid peroxidation and sialic acid levels and carbonic anhydrase activity. Brazilian Journal of Medical and Biological Research, 41, 956-959.

Rai, B. K. S., Jain, R., \& Anand, S. C. (2006). Salivary LPO product malonaldeyde in varius dental diseases. World Journal of Medical Sciences, 1, 100-101.

Sarode, G., Shelar, A., Sarode, S., \& Bagul, N. (2012). Association between dental caries and lipid peroxidation in saliva. International Journal of Oral and Maxillofacial Pathology, 3, 02-04.

Sculley, D. V., \& Langley-Evans, S. C. (2003). Periodontal disease is associated with lower antioxidant capacity in whole saliva and evidence of increased protein oxidation. Clinical Science, 105, 167-172.

Tóthová, L., Celecová, V., \& Celec, P. (2003). Salivary markers of oxidative stress and their relation to periodontal and dental status in children. Disease Markers, 34, 9-15.

Tóthova, L., Kamodyová, N., Cervenka, T., \& Celec, P. (2015). Salivary markers of Oxidative stress in oral diseases. Frontiers in Cellular an Infection Microbiology, 5 , $1-40$.

Tulunoglu, O., Demirtas, S., \& Tulunoglu, I. (2006). Total antioxidante levels of saliva in children related to caries, age: and gender. International Journal of Paediatric Dentistry, 16, 186-191.

Tunez, I., Feijoo, M., Huerta, G., Montilla, P., Munoz, E. Ruiz, A., \& Collantes, E. (2007). The effect of infliximab on oxidative stress in chronic inflammatory joint disease. Current Medical Research and Opinion, 23, 1259-1267.

Vadiakas, G. (2008). Case definition: aetiology and risk assessment of early childhood caries (ECC): a revisited review. European Archives of Paediatric Dentristry, 9, 114-125.

Varvara, G., Traini, T., Esposito, P., Caputi, S., \& Perinetti, G. (2005). Copper-zinc superoxide dismutase activity in healthy and inflamed human dental pulp. International Endodontic Journal, 38, 195-199.

WHO: Oral Health Surveys. Basic Methods, ed 4. Geneva, World Health Organization (1997).

Warren, J. J., Blanchette, D., Dawson, D. V., Marshall, T. A., Phipps, K. R., Starr, D., et al (2016). Factors associated with dental caries in a group of American Indian children at age 36 months. Community Dentistry an Oral Epidemiology, 44, 154161. 